\title{
The botanical legacy of Thomas Hardwicke's journey to Srinagar in 1796
}

\author{
Ian M. TURNER \\ Research Associate, Royal Botanic Gardens Kew, Richmond, Surrey, UK \\ Email: turner187@btinternet.com
}

\begin{abstract}
In 1796, Thomas Hardwicke travelled through northern India between what is now Fatehgarh in Uttar Pradesh and Srinagar in Uttarakhand. Hardwicke collected and described plants encountered and had many of the plants illustrated from life. He published an account of the journey in 1799 including a list of plant species. I review the names validated in the original paper, and also those published subsequently by Sir James Edward Smith and William Roxburgh based partly or wholly on the material or drawings acquired by Hardwicke on the journey to Srinagar. The large collection of Hardwicke plant drawings now held in the British Library, and a smaller set in the Botany Library of the Natural History Museum, are considered in relation to the application and typification of plant names related to Hardwicke's botanical exploration in India. The names of seven plant species were validly published in the 1799 paper (Androsace rotundifolia Hardw., Ficus laminosa Hardw., Justicia thyrsiformis Roxb. ex Hardw., Linum trigynum Roxb. ex Hardw., Lonicera quinquelocularis Hardw., Salvia integrifolia Roxb. ex Hardw. and Volkameria bicolor Hardw.), plus one new combination (Echites antidysentericus (L.) Roxb. ex Hardw.). As concluded by Britten more than a century ago, Ficus laminosa is the correct name for the fig variously referred to F. saemocarpa Miq. or F. squamosa Roxb. Smith based Rhododendron arboreum Sm. and Bignonia undulata Sm. on Hardwicke plants. At least a dozen Roxburgh names, including Crataegus integrifolia Roxb., Gardenia tetrasperma Roxb. and Morus serrata Roxb., are based, at least partly, on Hardwicke's collections. In total, 23 names are lectotypified here and one neotype is designated.
\end{abstract}

Keywords. India, Himalayas, James Edward Smith, lectotype, Thomas Hardwicke, William Roxburgh.

Turner I.M. 2015. The botanical legacy of Thomas Hardwicke's journey to Srinagar in 1796. European Journal of Taxonomy 108: 1-25. http://dx.doi.org/10.5852/ejt.2015.108

In short, in matters vegetable, animal, and mineral,

He is the very model of a modern Major-General

W.S. Gilbert, The Pirates of Penzance (1879)

\section{Introduction}

Thomas Hardwicke (1756-1835) was an Englishman (from the fens of Cambridgeshire) who rose through the ranks in the military service of the East India Company, eventually being promoted to Major-General (Dawson 1946). Hardwicke was very interested in natural history, apparently in nearly all its branches. He collected widely in India and elsewhere and employed (unnamed) Indian artists to 
prepare illustrations of animals and plants. When he returned to England on his retirement, Hardwicke possessed a large collection, particularly of illustrations, which was enlarged with drawings obtained from other naturalists such as John Reeves, who had worked in China. At his death, the collection was bequeathed and soon transferred to the British Museum (details given in Anonymous 1839), though a strict execution of Hardwicke's will would probably have resulted in the sale of the material to fulfil the financial bequests (Dawson 1946). The subsequent separation of various departments of the British Museum means that The Hardwicke Bequest is now divided across at least two institutions - the animal specimens and the bulk of the zoological drawings are in the Natural History Museum collections, the remaining drawings and manuscripts are in the British Library. Hardwicke's is a name much better known in zoological than botanical circles. Hardwicke published more extensively on animals than plants, and his superb drawings were the basis of Illustrations of Indian Zoology (Gray 1830, 18331834). However, I do not think that this should be taken to imply a lesser interest in botany than zoology on the part of Hardwicke. He maintained extensive correspondence with important figures in Indian botanical circles such as William Roxburgh and Nathaniel Wallich, and with Sir James Edward Smith and Aylmer Lambert in England.

Hardwicke's only foray into botanical publication is in what amounts to an appendix to a report of his travels through north-western India in 1796, describing the plants encountered. This was published in the Asiatick Researches (Hardwicke 1799). Daniel (1991) claimed that the paper by J.P. Rottler (1803) was the earliest account of a botanical collection and excursion in India, but Hardwicke's trip and publication are certainly earlier. Hardwicke's journey was to Sirinagur (Srinagar in contemporary spelling). This is Srinagar in what is now the Indian state of Uttarakhand, not the better-known place with the same name in Kashmir. Departing from Futtehghur (Fatehgarh, a long-established military base near Farrukhabad in what is now Uttar Pradesh), Hardwicke travelled to Srinagar via Hardwar (Haridwar) and Coadwara (Kotdwara), and returned to Fatehgarh. The visit to Haridwar coincided with the Kumbh Mela, an enormous gathering of pilgrims celebrating the most auspicious period for immersion in the holy river Ganges. Hardwicke reports some 2.5 million attendees, surely one of the largest aggregations of human beings up to that date. On the first part of the journey he was accompanied by Company surgeon, orientalist and naturalist Dr William Hunter.

Fortunately, the expedition was accompanied by at least one of Hardwicke's Indian artists and many drawings relating to the expedition are preserved in the collections. There is also correspondence showing that Roxburgh was consulted extensively about the plants found on the journey to Srinagar. Firstly using William Hunter as an intermediary, and then in letters exchanged directly, Roxburgh provided names for some of the species sent to him by Hardwicke as descriptions, specimens and drawings. Hardwicke was not particularly fastidious in acknowledging the help he received from Roxburgh in the Asiatick Researches paper, but the habit of sending plant descriptions to Roxburgh had been begun and would continue for many years, notably when Hardwicke was in Mauritius in 1811-1812. Roxburgh commemorated Hardwicke in the legume genus Hardwickia Roxb.

Hardwicke wanted to draw attention to his botanical research on the Srinagar expedition. He drew up a set of descriptions with accompanying illustrations for 22 species. This was submitted by Dr William Hunter to the Government of India in 1798 for forwarding to the Court of Directors of the East India Company (EIC) in London for the attention of the twin luminaries, Sir Joseph Banks and Sir James Edward Smith. Britten (1906) reported on this material in the Natural History Museum, which presumably came from Banks's collection, not as part of the Hardwicke Bequest, but originally from the EIC. Britten indicated that there were no herbarium specimens from the Srinagar expedition in the herbarium of the Natural History Museum (BM). This appears to have been an error. There are a few specimens, but most of the species seem not to be represented as herbarium material. Britten effectively lectotypified a few of Hardwicke's names to drawings in the set of 22 now held in the Botany Library 
TURNER I.M., Indian plant species discovered by Thomas Hardwicke

of the Natural History Museum. Britten made no mention of other relevant drawings in the Hardwicke material then kept in the manuscripts collection at the British Museum. These include a 16-volume set of Plants of India, now in the Western Manuscripts collection of the British Library, which contains duplicates of many of the drawings studied by Britten and other plants from the expedition, as well as drawings made both before and after. The drawings within each volume are numbered in a consecutive sequence with pencilled Arabic numerals in the top right corner. These are used to refer to individual drawings below. When Hardwicke returned to England on leave in 1804, he lent some of these plant illustrations to J.E. Smith. Smith used several of them as the basis for illustrations of species in his Exotic Botany (Smith 1804-1805), with some taxa entirely based on Hardwicke drawings. The drawings were not returned until 1812 when Hardwicke was again in England. In 1827, the plant drawings (in ten volumes with 60 loose items) were lent to William Hooker. There are also duplicates or copies of some of Hardwicke's illustrations among the natural history drawings in the Wellesley Collection (Archer 1962), now held in the Asia, Pacific and Africa collection of the British Library.

Britten (1906) was not the first to present an analysis of plant list in Hardwicke's narrative. Madden (1849) had included an accurate review of the identities of Hardwicke's plants, based, apparently, on his own knowledge of the flora of the region rather than study of the specimens or illustrations.

The nomenclatural relevance of Hardwicke's expedition comes in several interconnected strands. Firstly, there are the taxa validly published by Hardwicke in Asiatick Researches (Hardwicke 1799). Secondly, there are a few taxa validated by Smith in Exotic Botany. Thirdly, Roxburgh based a number of species in his Flora Indica partly or wholly on Hardwicke's specimens or descriptions.

Below I review the names relating to Hardwicke's journey to Srinagar published in Asiatick Researches (in the order in which they appear in the original publication), followed by those in the works of Smith and Roxburgh.

\section{Names published in the original paper}

\section{Justicia thyrsiformis}

Hardwicke described this plant, ascribing the name to Roxburgh. Though Roxburgh (in litt.) actually suggested 'thyrsiformis' as the epithet, he used 'thyrsiflora' in Flora Indica, and appears to have corrected Hardwicke in a pencil annotation on the relevant drawings in the Plants of India (Vol. V nos. 71 and 72). I can confirm the observation by Mabberley (1980) that there are no Hardwicke specimens of this species in the BM or K herbaria. I therefore designate the Hardwicke drawing in the Natural History Museum Botany Library as lectotype. I prefer to choose this over the British Library copies as the Natural History Museum set are individually mounted and accompanied by Hardwicke's manuscript descriptions.

Phlogacanthus thyrsiformis (Roxb. ex Hardw.) Mabb. in Manilal

Botany and History of Hortus Malabaricus: 83 (1980). - Justicia thyrsiformis Roxb. ex Hardw., Asiatick Researches 6: 349 (1799). — Lectotype (designated here): Hardwicke Drawing No. 16 (BM!). Fig. 1.

\section{Salvia integrifolia}

This name is cited in a paper on Roxburgh's Hortus Bengalensis (Turner 2013). Britten (1906) effectively lectotypified the Hardwicke name to the drawing in the Natural History Museum collection. There is a similar drawing in the British Library (Vol. III no. 62). 


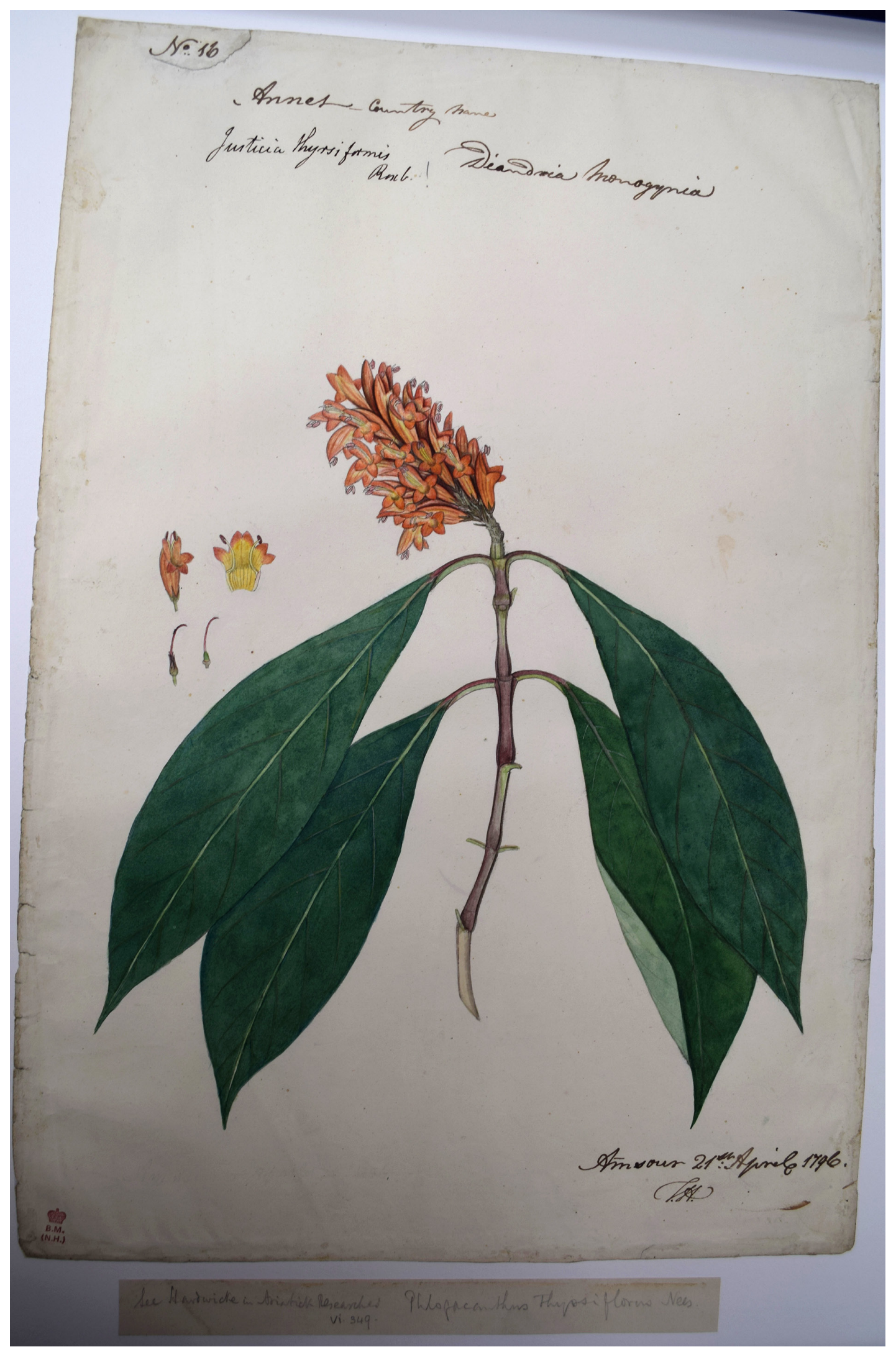

Fig. 1. Lectotype of Justicia thyrsiformis Roxb. ex Hardw., Hardwicke Drawing no. 16 from the collection of the Botany Library, Natural History Museum. (C) The Natural History Museum, London. 
Salvia cana Wall. ex Benth.

Edwards's Botanical Register 15: sub t. 1292 (1830). - Stenarrhena lanata D.Don, Prodromus Florae Nepalensis: 111 (1825). — Lectotype (designated by Turner 2013: 170): [India], Srinagar, Kamroop s.n. (BM!).

Salvia integrifolia Roxb. ex Hardw., Asiatick Researches 6: 349 (1799) (nom. illegit.) non Ruiz \& Pavon (1798: 26, t. 36). - Salvia lanata Roxb., Hortus Bengalensis: 80 (1814) (nom. illegit.) non Salisbury (1796: 74), nec Stokes (1812: 52). — Salvia mukerjeei Bennet \& Raizada, Indian Forester 108 (4): 303 (1982), 'mukerjeea'. — Lectotype (designated by Britten 1906: 44): Hardwicke Drawing no. 38 (BM!). Fig. 2.

\section{Ixora tomentosa}

Hardwicke's entry for this species is very brief:

"Ixora tomentosa of Doctor Roxburgh. - Found in the neighbourhood of Ghinouly near the Koanullah, acquires the size of a pretty large tree, though of deformed growth, now in flower. Flowers white, numerous."

It is questionable whether this description is sufficiently detailed to consider the name validly published here and as little would be gained from doing so, I will not take up the name from this source. There are drawings in the British Library (Vol. VII nos. 32-34) that show the plant is Pavetta tomentosa as validated by Sir J.E. Smith in Rees's Cyclopaedia (Rees 1814). Madden (1849) opined that the reference to deformed growth was the result of goat browsing. Roxburgh described Ixora tomentosa in the first edition of Flora Indica (Roxburgh 1820). He did not refer to Smith or Pavetta tomentosa but it seems simpler to invoke ICN (McNeill et al. 2012) Art. 41.4 and treat Ixora tomentosa as a new combination based on Pavetta tomentosa.

Pavetta tomentosa Roxb. ex Sm. in Rees

Cyclopaedia 26 (II): sp. no. 2 (1814). — Ixora tomentosa (Roxb. ex Sm.) Roxb., Flora Indica 1: 396 (1820). - Lectotype (designated here): Ind. Or., 1789, W. Roxburgh s.n. (LINN (LINN-HS 191.2) (photo!)).

\section{Androsace rotundifolia}

Though Hardwicke did not acknowledge him, it was Roxburgh (in litt.) who suggested 'rotundifolia' as the specific epithet for this species. There is a specimen in BM that has the same number as the drawing referred to by Britten (1906). There is also a drawing in the British Library set (Vol. IV no. 5) which is presumably the one that Smith had copied for the plate in Exotic Botany (Smith 1804-1805: t. 113).

Androsace rotundifolia Hardw.

Asiatick Researches 6: 350-351 (1799). — Lectotype (designated here): [India, one day's journey SW of Srinagar, 1796] T. Hardwicke 41 (BM! (BM000996974)).

\section{Lonicera quinquelocularis}

This is another case where Hardwicke did not state Roxburgh as the source of the binomial. The name was effectively lectotypified to the drawing in the Natural History Museum collection by Britten (1906). There is a similar illustration in the British Library (Vol. VII no. 67). There is also a specimen in the herbarium of the Natural History Museum (BM000945008). 


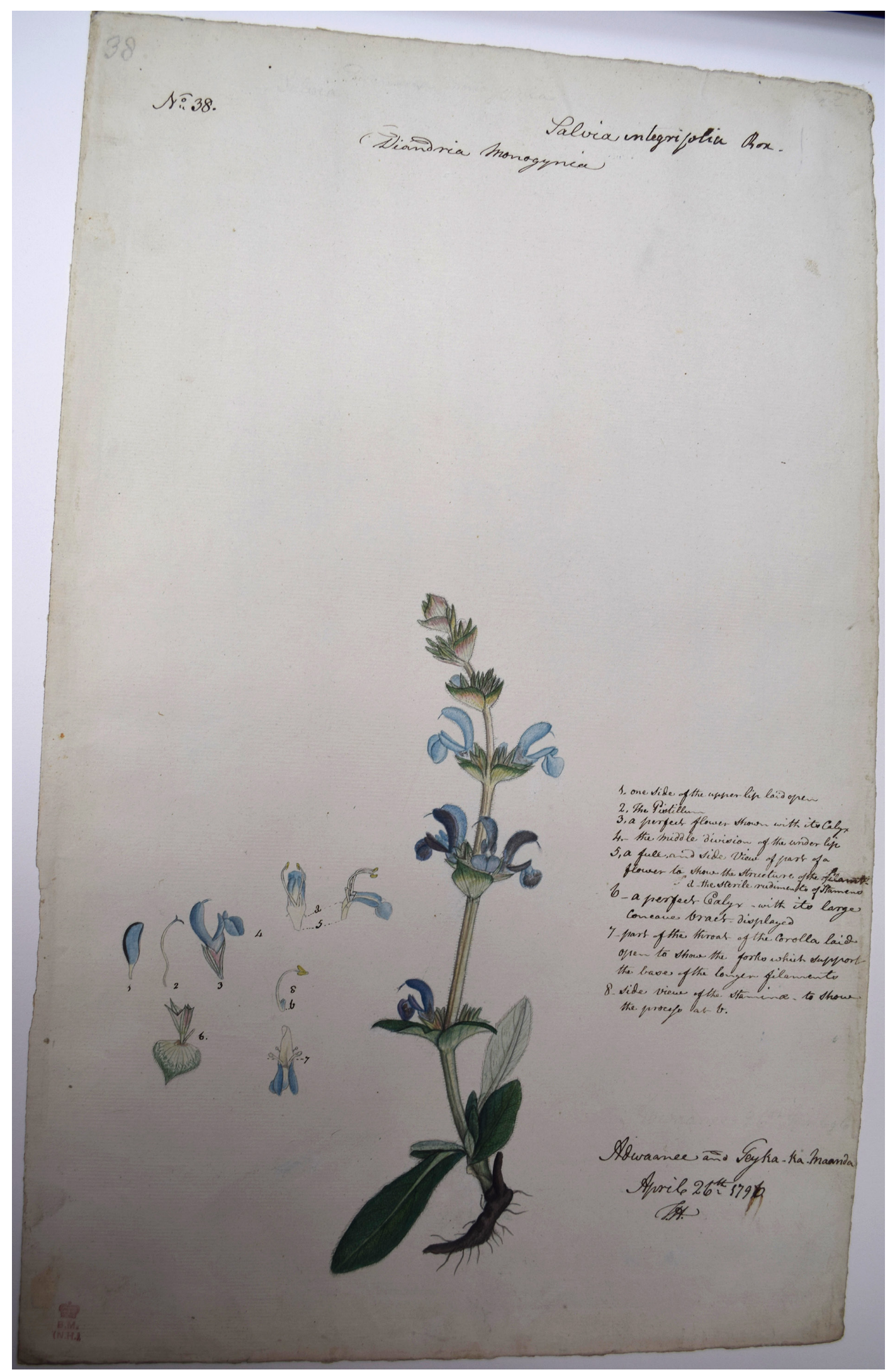

Fig. 2. Lectotype of Salvia integrifolia Roxb. ex Hardw., Hardwicke Drawing no. 38 from the collection of the Botany Library, Natural History Museum. (C) The Natural History Museum, London. 
TURNER I.M., Indian plant species discovered by Thomas Hardwicke

\section{Lonicera quinquelocularis Hardw.}

Asiatick Researches 6: 351 (1799). — Lectotype (designated by Britten 1906: 241): Hardwicke Drawing no. 67 (BM!). Fig. 3.

\section{Echites antidysentericus}

Hardwicke's entry for this species is as follows:

"Echites Antidysentricum Rox. - A small tree in the forests about Hurdwar. Leaves opposite, half or subpetioled, ovate, oblong, pointed, entire, waved, smooth, shining, one nerved, with many pairs of lateral, parallel, ribs. The Linnean characters of the fructification, do not strictly agree with this plant. The nectary is here wanting. Anthers almost at the bottom of the tube, filaments, scarcely any. The follicles agree with those of Nerium Antidysentricum. The seeds are in great repute among the natives of Hindustan as a vermifuge."

Hardwicke provided a reasonable description that clearly applies to the plant now known as Holarrhena pubescens Wall. ex G.Don. However, he also cited Nerium antidysentericum L. as a synonym. Linnaeus confounded two taxa in describing this species (Panigrahi 1987) - the Sri Lankan endemic, now referred to as Wrightia antidysenterica (L.) R.Br., and Holarrhena pubescens, which is widespread across East Africa and Asia (De Kruif 1981). As Hardwicke did not explicitly exclude Linnaeus's type or name from his Echites antidysentericus, it has to be considered a new combination based on Nerium antidysentericum. This represents an earlier publication of the combination than that by Fleming (1810).

Wrightia antidysenterica (L.) R.Br.

Asclepiadeae: 63 (1810). — Nerium antidysentericum L., Species Plantarum 1: 209 (1753). — Echites antidysentericus (L.) Roxb. ex Hardw., Asiatick Researches 6: 355 (1799), as 'antidysentricum'. Lectotype (designated by Trimen 1895: 138): Herb. Hermann 4: 76, no. 107 (BM (BM000594775)).

\section{Linum trigynum}

Hardwicke's description of this species is brief:

"It is perennial, shrubby, grows to a spreading bush about four feet high, stem and branches erect, slender, piped. It makes a handsome appearance with its numerous yellow flowers ..."

But I believe that it is adequate to validate Roxburgh's name Linum trigynum. It was accepted as such by botanists of this period. However, it is an illegitimate later homonym of the name of a European flax species described by Linnaeus. Dumortier (1822) described the same plant under the name Reinwardtia indica, which is the correct name for the species. Reichenbach (1837) effectively provided Macrolinum trigynum as a new name for L. trigynum Roxb. ex Hardw. Abdulla (1972) treated Linum trigynum and Reinwardtia indica as homotypic and referred to Roxburgh's icon no. 1048 at Kew as the type. This is effectively a neotypification as neither Hardwicke nor Dumortier are likely to have seen Roxburgh's drawing before publication of their respective names. I have not found any herbarium material of Reinwardtia indica collected by Hardwicke. There are two drawings in the British Library collection (Vol. XVI nos. 1 and 2). Drawing no. 1 has little information on it. Drawing no. 2 is good with detailed floral dissections. It is annotated 'Futtehghur Dec 1796' and 'a native of Sireenagur'. Futtehghur (Fatehgarh) was the departure point for the journey to Srinagar and its final destination. Hardwicke appears to have completed his writing up of the botanical material at Futtehghur (Britten 1906), so drawing no. 2 can be considered original material and is here selected as lectotype for Linum trigynum Roxb. ex Hardw. to supersede the neotypification of Abdulla. The drawing appears to be the basis of the plate (t. 17) in Smith's Exotic Botany. Dumortier did not cite any specimens of R. indica, and there are no specimens in BR (S. De Smedt, pers. comm.). I therefore select Smith's plate as the lectotype for 


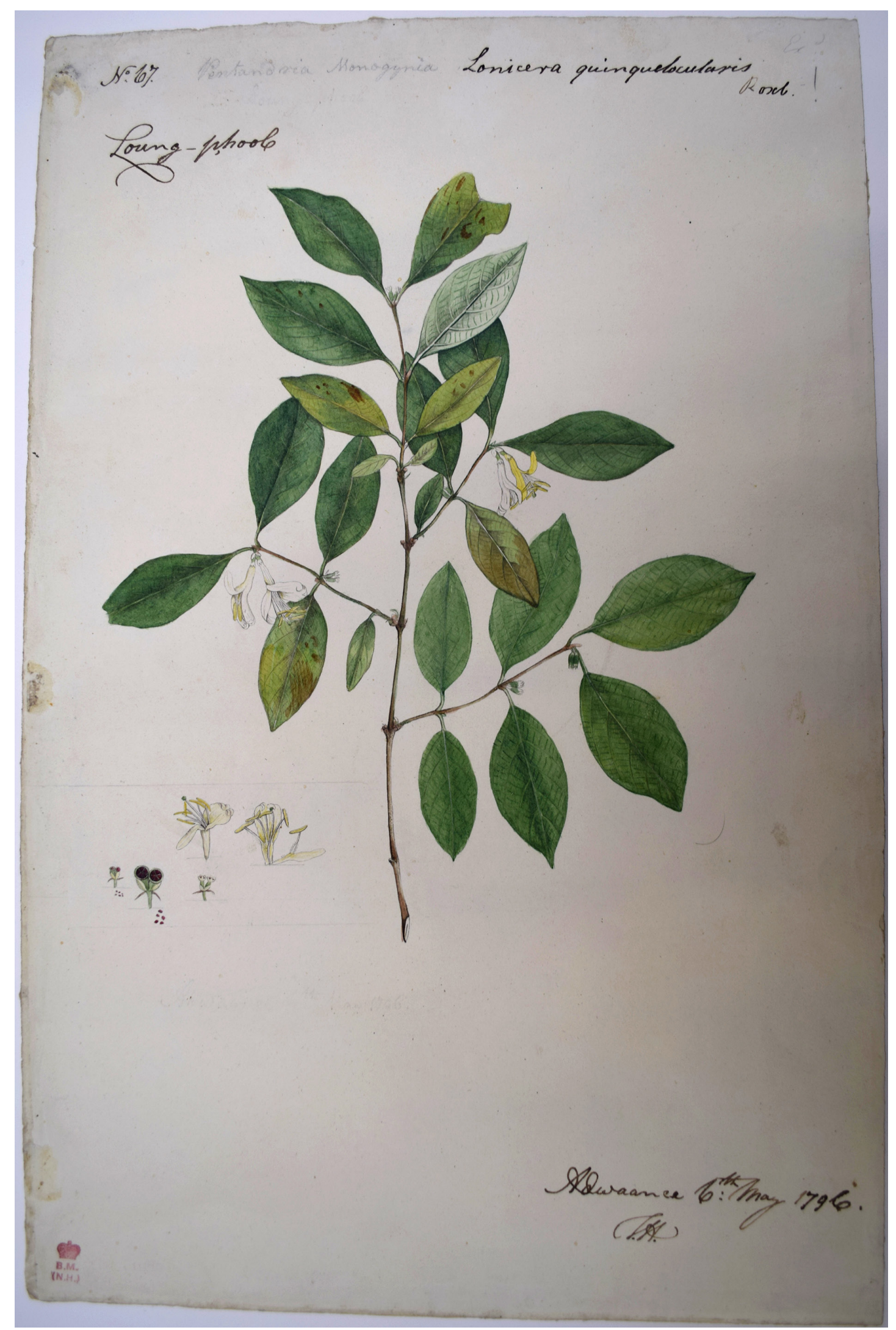

Fig. 3. Lectotype of Lonicera quiquelocularis Hardw., Hardwicke Drawing no. 67 from the collection of the Botany Library, Natural History Museum. (C) The Natural History Museum, London. 
TURNER I.M., Indian plant species discovered by Thomas Hardwicke

Reinwardtia indica as it was the only direct citation of an illustration by Dumortier, which again replaces Abdulla's typification.

\section{Reinwardtia indica Dumort.}

Commentationes Botanicae: 20 (1822). — Lectotype (designated here): Smith, Exotic Botany 1: t. 17 (1804).

Linum trigynum Roxb. ex Hardw., Asiatick Researches 6: 357 (1799), (nom. illegit.) non Linnaeus (1753: 279). - Macrolinum trigynum Rchb., Handbuch des Natürlichen Pflanzensystems: 307 (1837). - Reinwardtia trigyna (Rchb.) Planch., Hooker's London Journal of Botany 7: 522 (1848). - Kittelocharis trigyna (Rchb.) Alef., Botanische Zeitung 21: 282 (1863). — Lectotype (designated here): T. Hardwicke, Plants of India Vol. XVI (Add MS 11025): drawing no. 2 (British Library Western Manuscripts). Fig. 4.

\section{Lagerstroemia montana}

Hardwicke's descriptive statement for this name is slight:

"Lagerstroemia Montana, Roxburgh. - This tree grows to sixty or seventy feet high. Stem straight, thick, and clear of branches to a great height (forty feet). Flowers with much beauty in the month of May. Grows both above and below the ghats. Trees not numerous."

The name appears never to have been taken up elsewhere. There are three similar drawings in the British Library collection (Vol. X nos. 30-32) that represent this species. The first is annotated 'Coadwara 6 May 1796'; the second has a note saying 'No. 66 Cor Pl. vol 1'. This citation of Roxburgh's Plants of the Coast of Coromandel (Roxburgh 1795-1820) refers to Lagerstroemia parviflora Roxb. The drawings match L. parviflora, which was published before L. montana. Therefore, it seems best to consider Lagerstroemia montana as an invalidly published name. Surprisingly, Roxburgh did not originally recognise his own species, writing in August 1797 that Hardwicke's plant was "a charming new Lagerstroemia .... you must give it a specific name".

\section{Volkameria bicolor}

Hardwicke's description of this species is reasonably detailed. It was Roxburgh who had suggested 'bicolor' as the epithet. There is a specimen in BM that was designated lectotype by Mabberley. There are also drawings (no. 15 in the Natural History Museum set, and Vol. VI nos. 87 and 88 in the British Library).

\section{Pseudocaryopteris bicolor (Hardw.) P.D.Cantino}

Systematic Botany 23 (3): 381 (1999) [1998 publ. 1999]. — Volkameria bicolor Hardw., Asiatick Researches 6: 366 (1799). - Caryopteris bicolor (Roxb. ex Hardw.) Mabb. in Manilal, Botany and History of Hortus Malabaricus: 83. 1980. — Lectotype (designated by Mabberley 1980: 83): [India, Uttarakhand] sides of the Koa Nullah near Ansore [Amsaur], 1796, T. Hardwicke 15 (BM! (BM000889755)).

\section{Terminalia alata-glabra}

Hardwicke's description is brief.

"Terminalia Alata-glabra. - Grows to a very lofty tree in the vallies of these mountains. Stem streight, and clear from branches to a great height. The characters given to the genus Chuncoa, in Gmelin's edition of the Systema Naturae, agree well with this plant." 


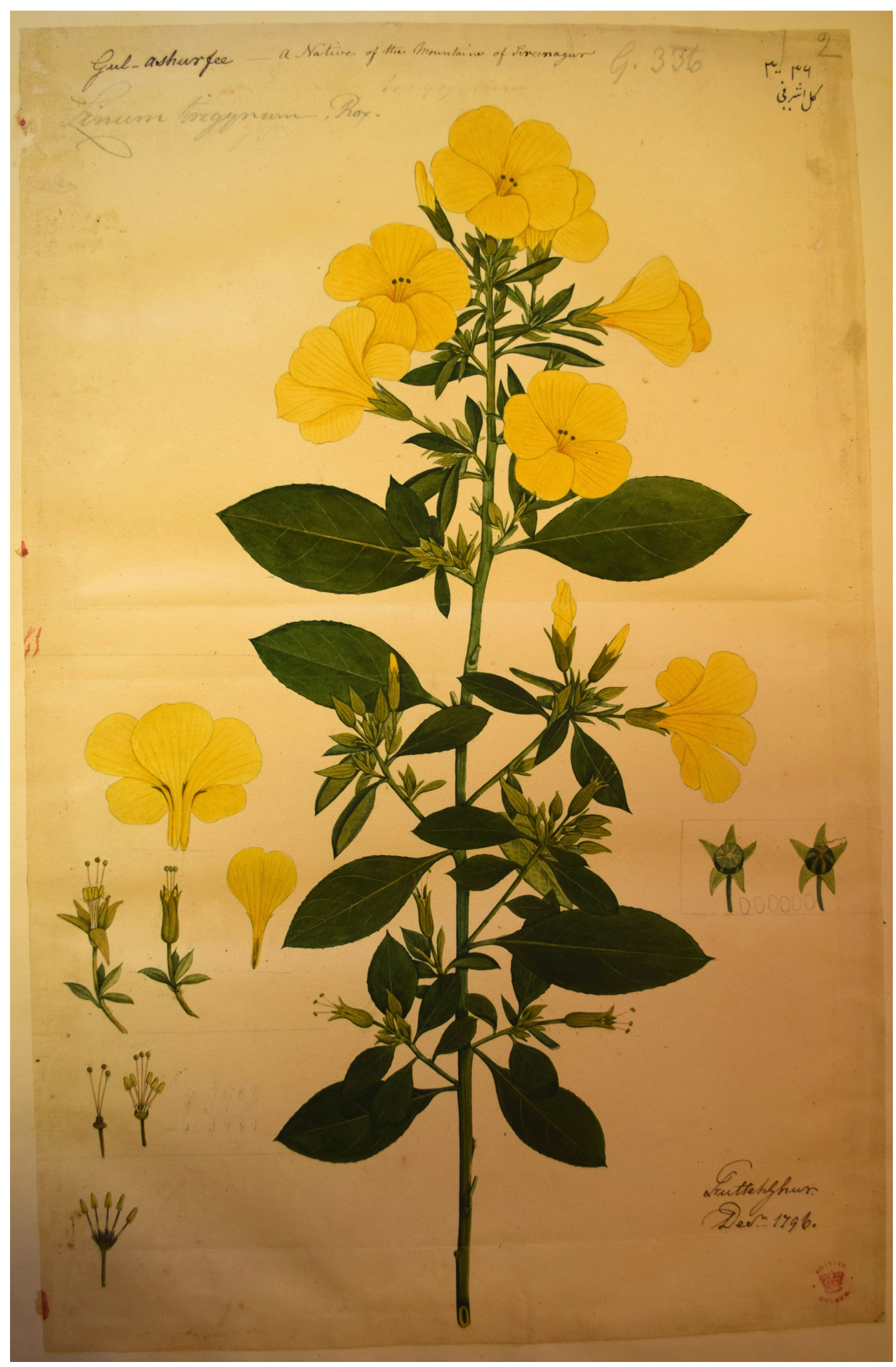

Fig. 4. Lectotype of Linum trigynum Roxb. ex Hardw., Hardwicke, Plants of India Vol. XVI (Add MS 11025): drawing no. 2. Reproduced with permission of the British Library Board. 
TURNER I.M., Indian plant species discovered by Thomas Hardwicke

Gmelin's description of Chuncoa cannot be cited to validate a species name as it refers to a genus (ICN Art. 38.11(c), McNeill et al. 2012). The remaining descriptive statement does not seem adequate to validate the name.

\section{Ficus laminosa}

Hardwicke's description is reasonably detailed:

"Ficus-laminosa. - An humble species, growing among detached rocks in a small water course, and other moist places along the valley of the Koa-nullah. The stem is procumbent, shrubby, diffuse. Leaves opposite, lanceolate, entire; fruit laminous. The natives collect the leaves to feed their cattle with, and call it Chancherree."

I reproduce the extract as published, including the internal hyphenation of the binomial. Various species names are similarly hyphenated in the original publication. I consider these typographic errors to be corrected, but others might cast doubt on the correct use of a binomial. However, the name did appear unhyphenated in the extract version of Hardwicke's paper in the Asiatic Annual Register (Hardwicke 1801). Correspondence indicates that it was Roxburgh who suggested the name to Hardwicke.

Britten (1906) pointed out that Ficus laminosa is the correct name for the fig species variously referred to as Ficus saemocarpa Miq. or F. squamosa Roxb. Unfortunately, his publication seems to have been overlooked by all subsequent fig specialists, a lacuna reinforced by the absence of any Hardwicke herbarium material of this species. The drawing no. 65 referred to by Britten is here designated lectotype of the species. There is a similar drawing in the Plants of India set (Vol. III no. 9).

Ficus laminosa Hardw.

Asiatick Researches 6: 379 (1799). — Lectotype (designated here): Hardwicke Drawing no. 65 (BM!). Fig. 5.

Ficus squamosa Roxb., Flora Indica 3: 531 (1832). — Lectotype (designated here): W. Roxburgh s.n. (BR (BR0000005228485)).

Ficus saemocarpa Miq., Annales Musei Botanici Lugduno-Batavi 3: 232-233 (1867). — Lectotype (designated here): India, Sikkim, 2000 feet, J.D. Hooker s.n. (U (U 0043108)).

Ficus pyrrhocarpa Kurz, Journal of the Asiatic Society of Bengal. Part 2. Natural History 42(2): 106 (1873). — Lectotype (designated here): Nepal, Noakote, March 1821, N. Wallich s.n. [EIC 4539 in part] (K-W!, central fruiting shoot labelled 'B' in pencil, other material explicitly excluded).

\section{Hardwicke plants named by Sir James Edward Smith}

Smith had access to Hardwicke's Indian plant drawings and used these in describing several species in his Exotic Botany.

\section{Rhododendron arboreum}

Probably the most important of these Smith names is Rhododendron arboreum. Smith acknowledged that the species was based entirely on Hardwicke's description and drawing. Hardwicke had included it as 'Doubtful' on pp. 359-360 in his paper but did not provide a name. Britten (1906: 240) wrote, in reference to drawing no. 40 in the Natural History Museum collection, 'the drawing is practically the type of Exotic Botany, tab. 6'. I take this to be an effective lectotypification of Rhododendron arboreum $\mathrm{Sm}$. to drawing 40 . The use of 'practically' has a degree of ambiguity but in the literal sense - for practical purposes - it seems acceptable and it is clear that the section refers to Rhododendron arboreum. 


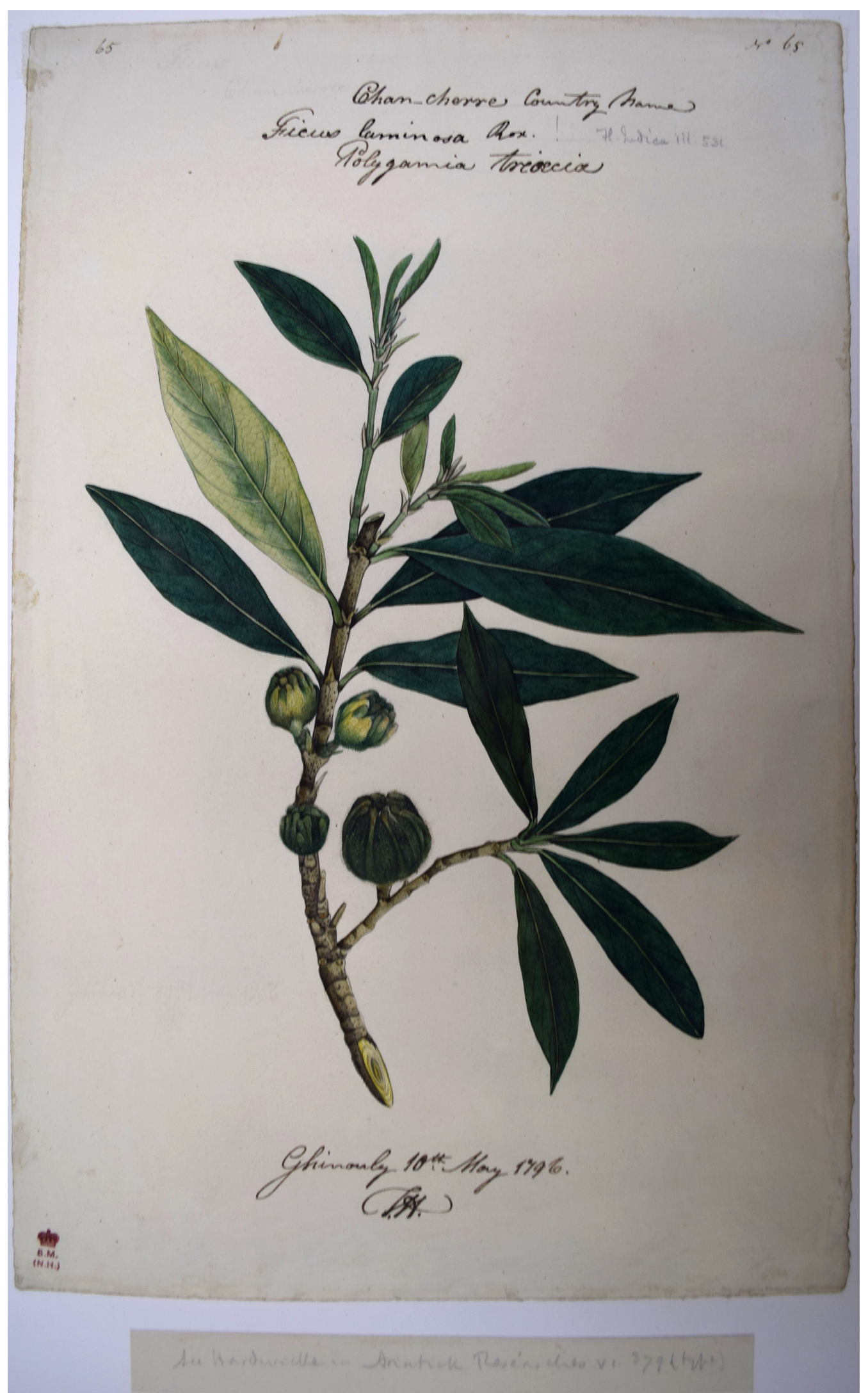

Fig. 5. Lectotype of Ficus laminosa Hardw., Hardwicke Drawing no. 65 from the collection of the Botany Library, Natural History Museum. (C) The Natural History Museum, London. 
TURNER I.M., Indian plant species discovered by Thomas Hardwicke

In the absence of any Hardwicke specimens, the choice of type seems limited to the illustrations which comprise drawing 40, a drawing in the British Library set (Vol. VII no. 23) and Smith's published illustration (t. 6). Britten's selection does not therefore present any problems, and, surprisingly, I have not found any other attempts to designate a type for this species.

Hardwicke's description was used to validate another name. Raper (1810) produced a long report on another expedition to the same area of India as Hardwicke's. This was communicated to the Asiatic Society by, the then President, H.T. Colebrooke. The published account in Asiatick Researches contains a number of footnotes - the first of which states that the note is by the President. Raper's account mentions a number of plant species, mostly using vernacular names. For boorans, the native name reported by Hardwicke for Rhododendron arboreum, there is a footnote that gives the name Rhododendron puniceum Roxb. and a direct reference to Hardwicke's description. This link provided by Colebrooke between Roxburgh's name and Hardwicke's description validates Rhododendron puniceum more than 20 years prior to its publication in Flora Indica. I lectotypify R. puniceum to the Plants of India copy of the drawing. In fact, Roxburgh did see the Hardwicke drawing of boorans. William Hunter, in a letter of 24 September 1797, included a request from Roxburgh for another copy of the drawing as his had been ‘carried away' by Sir J. Murray (possibly Sir John Murray 1745-1822, Auditor General of Bengal).

\section{Rhododendron arboreum Sm.}

Exotic Botany 1: 9-10, t. 6 (1805). — Lectotype (designated by Britten 1906: 240): Hardwicke Drawing no. 40 (BM!). Fig. 6.

Rhododendron puniceum Roxb. ex Colebr. in Raper, Asiatick Researches 11: 468 (1810). — Lectotype (designated here): T. Hardwicke, Plants of India Vol. VII (Add MS 11016): drawing no. 23 (British Library Western Manuscripts).

\section{Bignonia undulata}

In describing Bignonia undulata, Smith wrote that the species was discovered by Hardwicke who conveyed living plants to Calcutta, but he did not explicitly state that the description was taken from Hardwicke. The species is not included in Hardwicke's Asiatick Researches paper, but the plant was undoubtedly found by Hardwicke. There is drawing no. 33 in the Natural History Museum set and four drawings (Vol. V nos. 57-61) in the British Library. Of these, Vol. V no. 57 comes closest to Smith's tab. 19, though it appears to be laterally reversed. I here lectotypify Bignonia undulata, now known as Tecomella undulata (Sm.) Seem., to Smith's plate.

Tecomella undulata (Sm.) Seem.

Journal of Botany 1: 18 (1863). — Bignonia undulata Sm., Exotic Botany 1: 35, t. 19 (1805). - Tecoma undulata (Sm.) G.Don, General History 4: 223 (1838). — Lectotype (designated here): Smith, Exotic Botany 1: t. 19. 1805.

It should be noted that an earlier publication of Tecomella undulata listed in the International Plant Names Index (IPNI) (Seemann 1862: 30) is not valid on two counts: the generic name was invalid in the absence of a description and the combination was not validly made.

\section{Dillenia aurea}

Another species described by Smith entirely based on Hardwicke's drawings is Dillenia aurea. This was not found by Hardwicke on the expedition to Srinagar, but came from much further east, probably in what is now Bangladesh. There are drawings in the British Library collection (Vol. XVI, nos. 70 and 


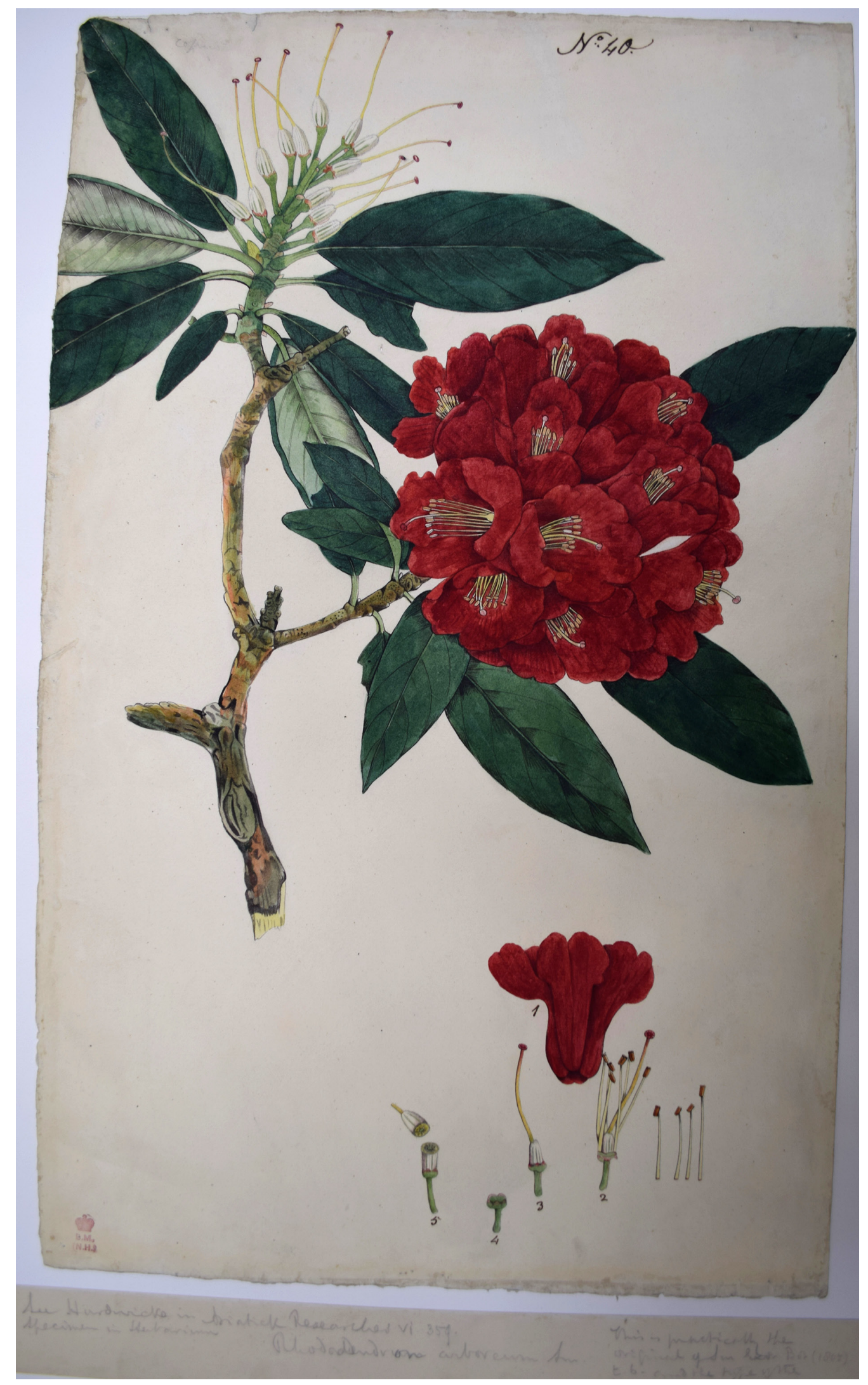

Fig. 6. Lectotype of Rhododendron arboreum Sm., Hardwicke Drawing no. 40 from the collection of the Botany Library, Natural History Museum. (C) The Natural History Museum, London. 
TURNER I.M., Indian plant species discovered by Thomas Hardwicke

71) that are clearly the source for Smith's plates; indeed they bear pencil annotations of 'Tab. 92' and 'Tab. 93'.

\section{Dillenia aurea Sm.}

Exotic Botany 2: 65, tt. 92-93 (1806). — Lectotype (designated here): Smith, Exotic Botany 2: t. 92. 1806.

\section{Hastingia coccinea}

Hastingia coccinea was described by Smith based on a specimen sent to Sir Joseph Banks and a drawing from Hardwicke. The name is a synonym of Holmskioldia sanguinea Retz. Smith's plate (t. 80) is based on a drawing in the British Library collection (Vol. VI no. 99) which is annotated in pencil 'Tab. 80' at the top and 'to be tab. 80 ' in the lower right corner. The same hand has noted 'drawing unfinished in many aspects'.

The typification of Holmskioldia sanguinea Retz. has a rather convoluted history. Fischer (1932: 160) noted that there was a relevant specimen in the Lund Herbarium, but his comment that it was 'presumably the type' seems too indefinite to be considered effective. Moldenke (1981) referring to the same specimen as 'probably the type and should be so considered', made an effective lectotypification. There is a second Retzius specimen of this taxon in the Lund Herbarium (P. Frödén, pers. comm.) that was misplaced under another genus until 1993. It is clear that both Fischer and Moldenke were referring to the specimen long recognised as Holmskioldia.

\section{Holmskioldia sanguinea Retz.}

Observationes Botanicae 6: 31 (1791). — Lectotype (designated by Moldenke 1981: 341): Anon. [?J. Koenig] s.n. (LD (annot. 71.92) (photo!)).

Hastingia coccinea Sm., Exotic Botany 2: 41, t. 80 (1806). — Lectotype (designated here): Anon. s.n. (LINN (LINN-HS 1019.2) (photo!)).

Platunium rubrum Juss., Annales du Muséum national d'histoire naturelle 7: 76 (1806). — Lectotype (designated here): India orientalis, Herb. Jussieu Catal. no. 5029 (P-JU (IDC 6206, 347/14!)).

Hastingia scandens Roxb., Flora Indica 3: 66 (1832). — Type: not designated.

\section{Hardwicke plants published by William Roxburgh}

As noted above, Roxburgh was directly involved in naming many of the plants collected and drawn on the journey to Srinagar. However, Hardwicke's published list included a number of species only identified to genus, or in a few cases unidentified. Through further study, new collections or cultivation of material forwarded by Hardwicke, names were established for some of these. They were eventually published in Flora Indica, some more than 30 years later, and included reference to Hardwicke's work. I go through these in the order in which the cited descriptions had appeared in the Asiatick Researches paper.

\section{Jasminum chrysanthemum}

In describing this species, Roxburgh (1820) referred (among other material) to what Hardwicke called 'Jasminum 3'. The correct name for the plant is Jasminum humile L. Roxburgh's species seems not to have been typified. The Roxburgh drawing at Kew, now held by the Illustrations Section of the Library, Art \& Archive Department, is here selected as lectotype. 


\section{Jasminum humile L.}

Species Plantarum 1: 7 (1753). — Lectotype (designated by Green 1961: 365): Herb. Linn. no. 17.6 (LINN).

Jasminum chrysanthemum Roxb., Flora Indica 1: 98 (1820). — Lectotype (designated here): Roxburgh Icon 2009 (K!).

\section{Gardenia tetrasperma}

Hardwicke's 'Gardenia 3' appears to have been the sole basis of Roxburgh's Gardenia tetrasperma (Roxburgh 1824). Britten (1906) recognised this and effectively lectotypified Roxburgh's name to drawing no. 55 in the Natural History Museum set. There is a similar drawing in the British Library (Vol. VII no. 55). The accepted name is now considered to be Himalrandia tetrasperma.

Himalrandia tetrasperma (Roxb.) T.Yamaz.

Journal of Japanese Botany 45: 340 (1970). - Gardenia tetrasperma Roxb., Flora Indica 2: 555 (1824). — Lectotype (designated by Britten 1906: 240): Hardwicke Drawing no. 55 (BM!). Fig. 7.

\section{Arbutus herpetica}

Roxburgh (1832a) ascribed this binomial to Colebrooke and made reference to Hardwicke's 'Arbutus doubtful'. Before Roxburgh's publication appeared, however, Wallich had already referred to Arbutus herpetica and Hardwicke's drawing in describing Andromeda ovalifolia from Nepal. Wallich noted that the two did not agree in all respects. For simplicity, below I treat Arbutus herpetica as a synonym of Lyonia ovalifolia (Wall.) Drude, but Judd (1981), recognised a number of varieties to capture the variability of the species, and Arbutus herpetica probably is closest to his var. cordata. Below, I select the Hardwicke drawing no. 36 in the Natural History Museum set as the type of Arbutus herpetica. There is a similar drawing in the Plants of India set (Vol. VII no. 24).

\section{Lyonia ovalifolia (Wall.) Drude}

Die Natürlichen Pflanzenfamilien 4 (1, lief. 37): 44 (1889). — Andromeda ovalifolia Wall., Asiatick Researches 13: 391-392, unnumbered plate (1820). — Lectotype (designated here): Nepal, May 1818, Anon. s.n. (BM! (BM000521846)).

Arbutus herpetica Coleb. ex Roxb., Flora Indica 2: 412 (1832). - Lectotype (designated here): Hardwicke Drawing no. 36 (BM!). Fig. 8.

\section{Prunus silvatica}

Roxburgh (1832a) referred to Hardwicke's unnamed Prunus species in describing P. silvatica. There is a Roxburgh icon, for this plant, so it is not necessary to typify on Hardwicke material. Roxburgh's name is an illegitimate later homonym, but the Himalayan cherry had already received several validly published names.

\section{Prunus cerasoides D.Don}

Prodromus Florae Nepalensis: 239 (1825). — Lectotype (designated by Ghora \& Panigrahi 1984: 21): Nepal, Narainhetty, 26 October 1802, F. Buchanan-Hamilton s.n. (BM (BM000522036) (photo!)).

Cerasus puddum Roxb. ex Ser. in DC., Prodromus 2: 537 (1825). — Lectotype (designated here): Nepal, 1819, Anon. s.n. (G-DC (IDC 800/2, 439/19!)). 


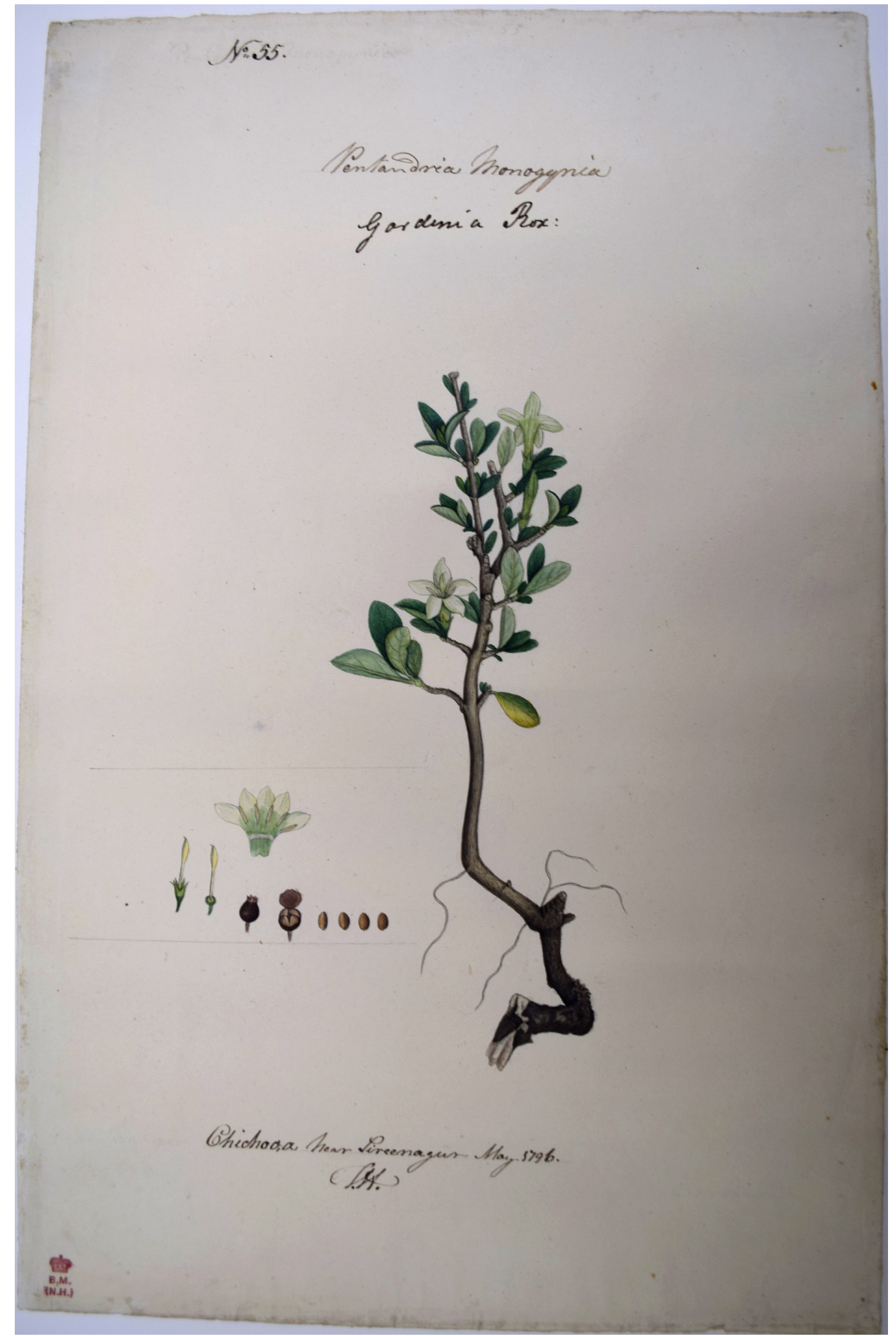

Fig. 7. Lectotype of Gardenia tetrasperma Roxb., Hardwicke Drawing no. 55 from the collection of the Botany Library, Natural History Museum. (C) The Natural History Museum, London. 


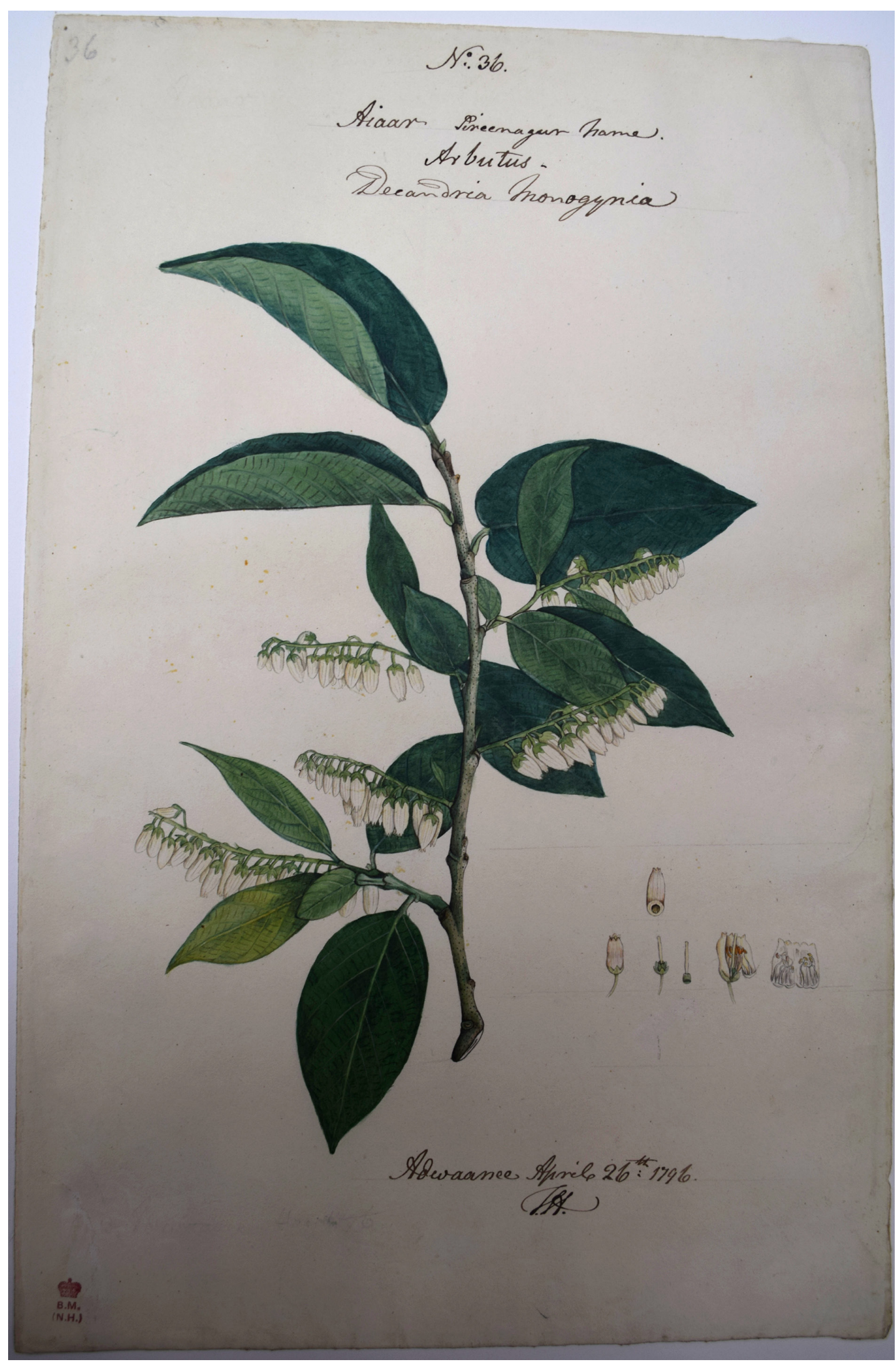

Fig. 8. Lectotype of Arbutus herpetica Coleb. ex Roxb., Hardwicke Drawing no. 36 from the collection of the Botany Library, Natural History Museum. (c) The Natural History Museum, London. 
TURNER I.M., Indian plant species discovered by Thomas Hardwicke

Prunus silvatica Roxb., Flora Indica 2: 501 (1832) (nom. illegit.) non Desvaux (1818: 160, as P. sylvaticus). — Lectotype (designated here): Roxburgh drawing 2265 (K!).

\section{Crataegus integrifolia}

Roxburgh (1832a) referred to Hardwicke's unnamed Crataegus in describing this species. Klotz (1963) transferred the species to Cotoneaster. With reference to typification ('Das Typenexemplar dieser Sippe konnte ich noch nicht prüfen; es müßte sich im Herbar Roxburghs befinden. Falls dort kein Typus von Crataegus integrifolia ist, kann Wallich no. 662 B als Lectotypus benutzt werden.'), Klotz failed to realise that a specimen suggested as a possible lectotype (K-W 662B), was, in fact, a Roxburgh specimen and has a ticket bearing Roxburgh's species name in his own hand. Kumar \& Panigrahi (1995) effectively chose a probable duplicate specimen in the Calcutta herbarium as lectotype.

\section{Cotoneaster integrifolius (Roxb.) G.Klotz}

Wissenschaftliche Zeitschrift der Martin-Luther-Universität Halle-Wittenberg. Mathematischnaturwissenschaftliche Reihe 12 (10): 779 (1963). - Crataegus integrifolia Roxb., Flora Indica 2: 509 (1832). - Lectotype (designated by Kumar \& Panigrahi 1995: 107): EIC 662 right-hand shoot (excluding other material on sheet) (CAL).

\section{Rubus gowreephul}

Hardwicke described two Rubus species in his paper. One he referred to Rubus idaeus L., the other was not provided with a specific epithet, but he gave a native name - 'gowry-phul' - which translates as 'claret-purple fruit' according to Madden (1849). Roxburgh (1832a) was clearly referring to Hardwicke's description of this plant in his account of Rubus gowreephul. He also wrote that Hardwicke introduced the plant to the Calcutta Botanic Garden. Roxburgh's specific epithet was printed as two separate words in Flora Indica. I contract them to one as subsequent authors have. There is a Roxburgh icon of the plant, presumably drawn from material grown at Calcutta. Hardwicke also had a drawing (Vol. X no. 55).

\section{Rubus ellipticus Sm. in Rees}

Cyclopaedia 30: Rubus species no. 16 (1815). - Lectotype (designated by Zandee \& Kalkman 1981: 109): Nepal, Ettaura, 9 April 1802, F. Buchanan-Hamilton s.n. (LINN-HS 902.71 (photo!)).

Rubus gowreephul Roxb., Flora Indica 2: 517 (1832), as 'gowree phul'. — Lectotype (designated here): Roxburgh icon 1854 (K!).

\section{Rubus rosiflorus}

Roxburgh (1832a) also referred to the second Rubus described by Hardwicke on page 364 of the Asiatick Researches paper. The reference to pinnate leaves and Hardwicke's Rubus idaeus description being the only other one included indicates that this is the plant intended by Roxburgh. I have not traced any Roxburgh material of Rubus rosiflorus. There are two drawings in the Plants of India set (Vol. X nos. 57 and 58). The latter is annotated 'Sreenagur 2 May 96', and I select this as lectotype. 


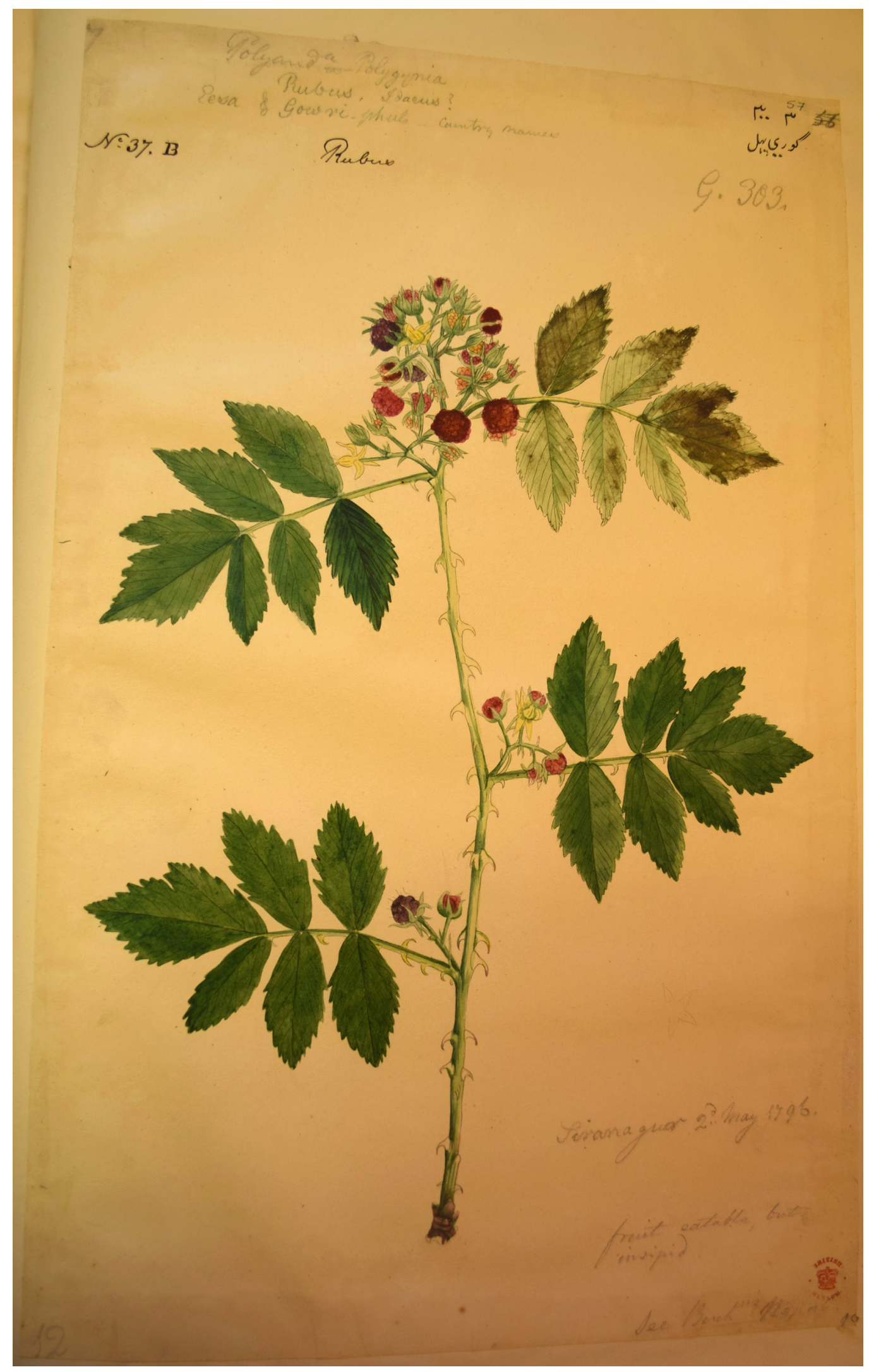

Fig. 9. Lectotype of Rubus rosiflorus Roxb., Hardwicke, Plants of India Vol. X (Add MS 11019): drawing no. 58. Reproduced with permission of the British Library Board. 
Rubus niveus Thunb.

Dissertationem botanico-medicam de Rubo: 7 \& 9, f. 3 (1813). — Type: Indonesia, Java, C.P. Thunberg s.n. (holo-: UPS (V-105490)).

Rubus rosiflorus Roxb., Flora Indica 2: 519 (1832), as 'rosaeflorus'. - Lectotype (designated here): T. Hardwicke, Plants of India Vol. X (Add MS 11019): drawing no. 58 (British Library Western Manuscripts). Fig. 9.

\section{Hypericum cernuum}

Roxburgh (1832b: 400) referred to Hardwicke's description of a Hypericum (of which there was only one) and that seeds of this were sent by Hardwicke to Calcutta for cultivation. There is a Hardwicke specimen of the plant in BM (no. 4 sides of High mountains Flos in April Figurd no. 4) and the matching drawing is in the British Library (Vol. XIV no. 60). Roxburgh's name for the plant had first been validated by David Don in the Prodromus Florae Nepalensis without reference to Hardwicke. Don referred to a Kamroop (a plant collector employed by Wallich) specimen from Srinagar. I could not find this in the BM collection where it would be expected. The earliest name for the species is Hypericum oblongifolium of Choisy, who apparently based his species on a Roxburgh specimen labelled Hypericum cernuum forwarded to de Candolle by Aylmer Lambert. The de Candolle Herbarium (G-DC) sheet including this material also contains a later specimen received from Wallich. The shoot with Roxburgh's ticket in his hand and another with the Lambert details are indicated as separate specimens with different barcode numbers, as does the third shoot from Wallich. I take the Roxburgh and Lambert elements to comprise a single specimen and consider them in combination to make up the holotype.

\section{Hypericum oblongifolium Choisy}

Prodromus d'une Monographie de la Famille des Hypéricinées: 42, t. 4 (1821). - Type: W. Roxburgh s.n. (holo-: G-DC (G00209992 - ex Herb. Lambert 1816 plus G00209991 ex Roxburgh labelled Hypericum cernuum, excluding G00209990 Wallich from Nepal 1821) (photo!)).

Hypericum cernuum Roxb. ex D.Don, Prodromus Florae Nepalensis: 218 (1825). Type: India, Uttarakhand, Srinagar, Kamroop (n.v.).

\section{Morus serrata}

In describing this species, Roxburgh (1832b) referred to Hardwicke's Morus 1. I have not found any Roxburgh material that could be used to typify this Himalayan mulberry. There are some Hardwicke drawings of Morus but none can be directly linked to Morus 1 of the Asiatick Researches paper. I therefore propose a neotype for the name - a collection made by R. Blinkworth from Kumaon in the East India Company Herbarium.

\section{Morus serrata Roxb.}

Flora Indica 3: 596 (1832). - Neotype (designated here): India, [Uttarakhand], Kumaon, s.dat., R. Blinkworth s.n. [EIC 6468A] (K-W!).

\section{Zanthoxylum alatum}

The Flora Indica description of this plant (Roxburgh 1832b) makes direct reference to Hardwicke's unnamed Zanthoxylum (as 'Xanthoxylum'), of which there is a drawing in the Natural History Museum set (no. 39) and a similar pair in the British Library (Vol. XIV nos. 7 and 8). Roxburgh's name, however, was cited by Wallich in his Numerical List, rendering it a superfluous, and illegitimate, renaming of 
Z. acanthopodium DC. Thus Roxburgh's name becomes an illegitimate later homonym. Hartley (1966: 211) proposed Roxburgh icon 1916 as the lectotype of Z. alatum Roxb. but he did not state which set of drawings (Kew or Calcutta) he was referring to. I therefore clarify the issue by proposing the Kew copy below.

\section{Zanthoxylum armatum DC.}

Prodromus 1: 727 (1824). — Lectotype (designated by Hartley 1966: 211, 212, 215): India, 1816, A. Lambert s.n. (G-DC, larger shoot in lower right corner only).

Zanthoxylum alatum Roxb., Flora Indica 3: 768 (1832), (nom. illegit.) non Roxb. ex Wall. in Wallich (1829: n. 1209). — Lectotype (designated here): Roxburgh Icon 1916 (K!).

\section{Ficus luducca}

Roxburgh (1832b) included two of the figs that Hardwicke found on his journey to Srinagar (Ficus luducca and F. chincha). Hardwicke included four Ficus species in his Asiatick Researches paper-Ficus laminosa and unnamed species numbered 2-4. There is no clear direct link to relate Hardwicke's species to Roxburgh's names, but the descriptions indicate, as supported by Madden (1849), that Hardwicke's 'Ficus 2' refers to Ficus luducca, and 'Ficus 3' to F. chincha. There is a Roxburgh specimen in the BR herbarium that must have come from Hardwicke judging by the collection label. Corner (1960b) effectively lectotypified the name to this specimen.

Ficus sarmentosa Buch.-Ham. ex Sm. var. luducca (Roxb.) Corner

Gardens' Bulletin, Singapore 18: 7 (1960). - Ficus luducca Roxb., Flora Indica 3: 534 (1832). - Lectotype (designated by Corner 1960b: 7): India, Dosah, 9 May [17]96, [T. Hardwicke s.n.] (BR0000005228348 (photo!)).

\section{Ficus chincha}

At BR there is a specimen of this species with a ticket bearing Roxburgh's name in Roxburgh's hand.

Ficus subincisa Buch.-Ham. ex Sm. in Rees

Cyclopaedia 14: Ficus sp. n. 91 (1810). — Lectotype (designated by Corner 1960a: 420): Nepal, Harainhetty, 28 January 1803, F. Buchanan-Hamilton s.n. (LINN-HS 1610.42).

Ficus chincha Roxb., Flora Indica 3: 534 (1832). — Lectotype (designated here): W. Roxburgh s.n. (BR0000005231270 (photo!)).

\section{Acknowledgements}

I am very grateful to John McNeill (E) for advice on a couple of nomenclatural queries arising from this work, and to Patrik Frödén (LD), Piet Stoffelen and Sofie De Smedt (BR) for information on specimens in their respective herbaria. Malini Roy very kindly provided assistance with access to the British Library collections. Henry Noltie (E) offered constructive comments on the manuscript.

\section{References}

Abdulla P. 1972. Linaceae. In: Nasir, E. \& Ali, S.I. (eds) Flora of West Pakistan 21: 1-6. Department of Botany, University of Karachi, Karachi. 
TURNER I.M., Indian plant species discovered by Thomas Hardwicke

Anonymous 1839. List of additions made to the collections in the British Museum in the year $M D C C C X X X V$. Printed by order of the Trustees, London.

Archer M. 1962. Natural history drawings in the India Office Library. Her Majesty's Stationery Office, London.

Britten J. 1906. Hardwicke's botanical drawings. Journal of Botany, British and foreign 44: 235-241.

Corner E.J.H. 1960a. Taxonomic notes on Ficus Linn., Asia and Australasia. I. Subgen. Urostigma (Gasp.) Miq. Gardens' Bulletin, Singapore 17: 368-441.

Corner E.J.H. 1960b. Taxonomic notes on Ficus Linn., Asia and Australasia. V. Subgen. Ficus sect. Rhizocladus, Kalosyce, Sinosycidium, Adenosperma, and Neomorphe. Gardens' Bulletin, Singapore 18: $1-35$.

Daniel P. 1991. Names validated in Rottler's "Botanical Obervations" of 1803. Taxon 40: 605-611. http://dx.doi.org/10.2307/1222769

Dawson W.R. 1946. On the history of Gray and Hardwicke's Illustrations of Indian Zoology, and some biographical notes on General Hardwicke. Journal of the Society for the Bibliography of Natural History 2: 55-69.

Desvaux N.A. 1818. Observations sur les plantes des environs d'Angers. Fourier-Mame, Angers.

Dumortier B.C.J. 1822. Commentationes botanicae. Ch. Casterman-Dieu, Tournay. http://dx.doi. org/10.5962/bhl.title.10534

Fischer C.E.C. 1932. The Koenig collection in the Lund Herbarium. Bulletin of Miscellaneous Information, Kew 1932: 49-76. http://dx.doi.org/10.2307/4113368

Fleming J. 1810. A catalogue of Indian medicinal plants and drugs, with their names in the Hindustáni and Sanscrit languages. Asiatick Researches 11: 153-196.

Ghora C. \& Panigrahi G. 1984. Rosaceae: Genus-Prunus. In: Nair, N.C. (ed.) Fascicles of Flora of India 18: 1-44. Botanical Survey of India, Calcutta.

Gray J.E. 1830. Illustrations of Indian zoology; chiefly selected from the collection of Major-General Hardwicke F.R.S., L.S., M.R.A.S., M.R.I.A., \& c., \&c. Volume I. Treuttel, Wurtz, Treuttel, Jun. and Richter, London. http://dx.doi.org/10.5962/bhl.title.95127

Gray J.E. 1833-1834. Illustrations of Indian zoology; chiefly selected from the collection of MajorGeneral Hardwicke F.R.S., L.S., M.R.A.S., M.R.I.A., \&c., \&c. Volume II. Adolphus Richter and Co., London.

Green P.S. 1961. Studies in the genus Jasminum I: section Alternifolia. Notes from the Royal Botanic Garden Edinburgh 23 (3): 355-384.

Hardwicke T. 1799. Narrative of a journey to Sirinagur. Asiatick Researches 6: 309-381.

Hardwicke T. 1801. Narrative of a journey to Sirinagur. Asiatic Annual Register 1800: 244-277.

Hartley T.G. 1966. A revision of the Malesian species of Zanthoxylum (Rutaceae). Journal of the Arnold Arboretum 47 (3): 171-221.

Judd W.S. 1981. A monograph of Lyonia (Ericaceae). Journal of the Arnold Arboretum 62: 63-209.

Klotz G. 1963. Neue oder kritische Cotoneaster-arten II. Wissenschaftliche Zeitschrift der MartinLuther-Univerität Halle-Wittenberg, Mathematisch-Naturwissenschaftliche Reihe 12: 769-786.

Kruif A.P.M. de 1981. A revision of Holarrhena R.Br. (Apocynaceae). Mededelingen Landbouwhogeschool Wageningen 81-2: 1-40. 
Kumar A. \& Panigrahi G. 1995. The family Rosaceae in India (Revisionary studies on Cotoneaster Medik.). Bishen Singh Mahendra Pal Singh, Dehra Dun.

Linnaeus C. 1753. Species Plantarum. Volume 1. Laurentii Salvii, Stockholm. http://dx.doi.org/10.5962/ bhl.title. 669

Mabberley D.J. 1980. A re-examination of the 'Indian Catalogues' with particular reference to Hortus Malabaricus. In: Manilal, K.S. (ed) Botany and History of Hortus Malabaricus: 80-110. Oxford \& IDH Publishing, New Delhi.

Madden E. 1849. Supplementary notes to "The Turaee and outer mountains of Kumaon;". Journal of the Asiatic Society of Bengal 18: 603-644.

McNeill J., Barrie F.R., Buck W.R., Demoulin V., Greuter W., Hawksworth D.L., Herendeen P.S., Knapp S., Marhold K., Prado J., Prud'homme van Reine W.F., Smith G. F., Wiersema J.H. \& Turland N.J. (eds) 2012. International Code of Nomenclature for Algae, Fungi, and Plants (Melbourne Code). Regnum Vegetabile 154. Koeltz Scientific Books, Königstein.

Moldenke H.N. 1981. Notes on the genus Holmskioldia (Verbenaceae). Phytologia 48: 313-356.

Panigrahi G. 1987. Echites antidysenterica (L.) Roxb. ex Fleming and Holarrhena antidysenterica (L.) Wall., validly published synonyms of Wallida antidysenterica. Taxon 36: 464-467. http://dx.doi. org/10.2307/1221451

Raper F.V. 1810. Narrative of a survey for the purpose of discovering the sources of the Ganges. Asiatick Researches 11: 446-563.

Rees A. 1814. The Cyclopaedia. Volume 26 section II. Longman, Hurst, Rees, Orme, \& Brown, London.

Reichenbach H.G.L. 1837. Handbuch des natürlichen Pflanzensystems. Arnoldischen Buchhandlung, Dresden \& Leipzig. http://dx.doi.org/10.5962/bhl.title.7598

Rottler J.P. 1803. Botanische Bermerkungen auf der Hin- und Rückreise von Trankenbar nach Madras vom Herrn Missionair Rottler zu Trankenbar mit Anmerkungen von Herrn Professor C. L. Willdenow. Der Gesellschaft Naturforschender Freunde Westphalens neue Schriften. Düsseldorf. 4: 180-225.

Roxburgh W. 1795-1820. Plants of the Coast of Coromandel. W. Bulmer \& Co., London. http://dx.doi. org/10.5962/bhl.title.467

Roxburgh W. 1820. Flora Indica. First edition. Volume 1. Mission Press, Serampore.

Roxburgh W. 1824. Flora Indica. First edition. Volume 2. Mission Press, Serampore.

Roxburgh W. 1832a. Flora Indica. Second edition. Volume 2. W. Thacker \& Co., Calcutta.

Roxburgh W. 1832b. Flora Indica. Second edition. Volume 3. W. Thacker \& Co., Calcutta.

Ruiz H. \& Pavon J. 1798. Flora Peruviana, et Chilensis. Volume 1. Gabrielis de Sancha, Madrid.

Salisbury R.A. 1796. Prodromus stirpium in horto ad Chapel Allerton vigentium. London. http://dx.doi. org/10.5962/bhl.title.427

Seemann B. 1862. Revision of the natural order Bignoniaceae. Annals and Magazine of Natural History ser. 3, 10: 29-33.

Smith J.E. 1804-1805. Exotic Botany. Two volumes. R. Taylor \& Co., London.

Stokes J. 1812. A Botanical Materia Medica. Volume 1. J. Johnson \& Co., London.

Trimen H. 1895. A Hand-Book to the Flora of Ceylon. Volume 3. Dulau \& Co., London. 
Turner I.M. 2013. Robinson a century on: the nomenclatural relevance of Roxburgh's Hortus Bengalensis. Taxon 62: 152-172.

Wallich N. 1829. A numerical list of dried plants in the East India Company's museum. Nos. 1-2153. East India Company, London. http://dx.doi.org/10.5962/bhl.title.1917

Zandee M. \& Kalkman C. 1981. The genus Rubus (Rosaceae) in Malesia. 1. Subgenera Chamaebatus and Idaeobatus. Blumea 27: 75-113.

Manuscript received: 17 May 2014

Manuscript accepted: 12 November 2014

Published on: 6 January 2015

Topic editor: Thomas Janssen

Desk editor: Natacha Beau

Printed versions of all papers are also deposited in the libraries of the institutes that are members of the EJT consortium: Muséum national d'Histoire naturelle, Paris, France; Botanic Garden Meise, Belgium; Royal Museum for Central Africa, Tervuren, Belgium; Natural History Museum, London, United Kingdom; Royal Belgian Institute of Natural Sciences, Brussels, Belgium; Natural history Museum of Denmark, Copenhagen, Denmark. 